\title{
Gellnerova periodizace očima historika
}

\author{
Miroslav Hroch*
}

\section{Gellner's Periodization through the Eyes of a Historian}

\begin{abstract}
The contribution tries to demonstrate possibilities of interelations between history and social sciences and presents a critical analysis of Gellner's book from the point of view of a historian. It deals above all with his interpretation of the transition from the time of the "sword" and that of the "book", which means to a historian the transition from the pre-modern towards the modern society. The author argues that historians have above all problems with Gellner's unconcern with defining time and space of analyzed processes. On the other side, he highly appreciates sophisticated reflections about the internal coordinates of agrarian society and about conditions of "escape" towards modernity. In comparison with other concepts of transition, Gellnerian approach could be located not very far from some basic aspects of historical materialism. Unfortunately, he ignores the older discussions on transition towards capitalism, like the "Brenner-debate” or Immanuel Wallerstein.
\end{abstract}

Keywords: periodization, historical change, agrarian society, capitalism, modernity

Když jsem počátkem devadesátých let pozval Ernesta Gellnera, aby na půdě Ústavu světových dějin představil svoji nově vydanou knihu Plough, Word and Book [1988], uvedl svoji přednášku tím, že označil svoje členění dějin lidstva jako pokus vytvořit alternativu proti marxistické periodizaci dějin. Pod tímto zorným úhlem jsme pak s Gellnerem diskutovali. Tato epizoda možná zapůsobila také na můj přístup k četbě jeho knihy, při níž mne především zajímal problém přechodu mezi jednotlivými formacemi, i když si uvědomuji, že periodizační aspekt je jen jedním z mnoha rovin jeho práce.

Jestliže se tedy tento př́spěvek zabývá právě touto otázkou, jde zajisté jen o jeden z mnoha problémů, jimž je Gellnerova kniha věnována. A možná, že termín „periodizace“ v tomto kontextu není přesný, protože je př́iliš široký a hlavně př́liš specifický nástroj v instrumentáriu historické vědy. Navíc mi zde nepůjde o periodizace vcelku, ale pouze o analýzu a výklad přeměny agrární společnosti ve společnost moderní, což je problém pro historickou vědu vůbec a pro mne zvláště velmi důležitý. ${ }^{1}$

Pro každého řadového, ve filozofii dějin neškoleného historika je velmi náročné zabývat se vysoce teoretickými statěmi filozofujícího antropologa. Vyplatí se nicméně hledat v nich poučení nebo přinejmenším inspiraci. Zároveň je ovšem Gellnerova konstrukce jistou výzvou, jistým „konkurenčním“ konstruktem, který stojí za kritické zamyšlení. Proto je pochopitelné (a je třeba na to hned úvodem upozornit), že historik bude mít s jeho přístupem $\mathrm{k}$ dějinám nejméně tři problémy.

* Prof. PhDr. Miroslav Hroch, DrSc., Fakulta humanitních studií Univerzity Karlovy, U Kř́̌̌̌e 8, 15800 Praha 5 - Jinonice. E-mail: hrochmir@seznam.cz

1 Referenčním objektem této diskuzní studie je zmíněná Gellnerova práce, Meč, pluh a kniha, která vyšla v českém jazyce v Brně v nakladatelství Centrum pro studium demokracie a kultury v roce 2001. Veškeré odkazy v textu se váží na první anglické vydání knihy, Plough, Sword and Book. The Structure of Human History. London: Collins Harvill, 1988. 
Prvý se týká časového určení. Historici jsou zvyklí vědět, na kterém místě časové osy se právě nacházejí, potřebují tuto chronologii jako berličku. Koneckonců, nejednou jsem studenty historie (i své kolegy) přesvědčoval o tom, že jedinou vpravdě historickou metodou je diachronní vyprávění a že všechny ostatní metody jsou vypůjčeny z jiných sociálních věd. Takové vyprávění ovšem u Gellnera zcela chybí: je sice jasné, že jedna kategorie procesů probíhala časově dříve než druhá, ale - nemýlím-li se - v celém textu není ani jediné explicitní časové vřazení do století či desetiletí. Určitou orientaci v čase umožňují jen odkazy na jisté historické procesy či osobnosti. Když hovoří o reformaci, zmiňuje Adama Smithe apod.

Na tuto výhradu zajisté je možno odpovědět, že historický vývoj probíhal asynchronně, takže jeden a týž jev či vztah může být datován v různých částech světa rozdílně. Nejsem si však jist, zda taková odpověd by byla „gellnerovská“. Je totiž pozoruhodné, že fenomén synchronického nebo asynchronního průběhu historických procesů v různých částech Evropy je u Gellnera tematizován jen velmi zřídka, a proto je možné vyjádřit domněnku, že to jsou kategorie, které jej nezajímaly.

Druhý problém se týká prostoru. Obvykle se dá odhadnout, zda je v Gellnerových úvahách řeč o Evropě či o ostatních kontinentech, ale již sama Evropa je prostor značně diferencovaný. Fenomén nerovnoměrnosti bez geografické diferenciace tak nemůže být předmětem hlubší analýzy.

Navíc se můžeme obvykle nad textem jen dohadovat, zda základní periodizační schéma, základní typy, modely mezilidských vztahů - symbolicky označené termíny pluh, meč a kniha - jsou konstruovány pro vývoj evropské společnosti, nebo zda se s nimi setkáme také ve společnostech mimoevropských. Někdy je zřejmé, že autor bere v úvahu také mimoevropské civilizace, jindy to je nejasné. At̉ je tomu již tak či onak, zůstává zde otevřený problém: vyplýval přechod od jedné struktury k další z vnitřního uspořádání oné výchozí, předcházející, nebo šlo o transfer z nejrychleji se vyvíjející společnosti západoevropské do ostatních částí světa? V prvém případě bychom zde měli co činit s fenoménem „zákonité“ změny v dějinách, pokud by platil druhý případ, museli bychom se vypořádat $s$ tím, kam zařadit předantické starověké civilizace - mezopotamskou, indickou, egyptskou, kde by bylo nesmyslné o transferu z (méně vyvinuté) Evropy hovořit.

V jednom případě však nám Gellner historické procesy lokalizuje velmi přesně, a to je v př́padě zrodu moderní (průmyslové) společnosti na území Anglie, případně také Nizozemí [Gellner 1988: 135]. Mohli bychom tedy podle toho usuzovat, že podle Gellnerova názoru přechody od společnosti „pluhu“ ke společnosti „meče“ probíhaly nezávisle na sobě, tedy „zákonitě“ $v$ různých částech světa, zatímco přechod ke společnosti „knihy“ byl dílem transferu z nejvyspělejší části Evropy?

Třetí problém vyplývá možná ze snahy historika, jenž uznává potřebu zobecňujícího pohledu na minulost a nezná nuance pojmosloví antropologického. Je však dost dobře možné, že Gellner si neláme hlavu s variabilitou svého pojmosloví: pro označení jedné a téže epochy, jednoho a téhož procesu uživá totiž rozdílných termínů, o nichž se čtenář může jen dohadovat, zda je autor chápe jako synonyma či nikoli. To se týká bohužel i termínů vztahujících se k periodizaci. Proto Gellnerovu periodizaci vývoje lidstva budu charakterizovat spíše „obsahem“, který s jednotlivými epochami spojuje, než termíny, jichž přitom užívá pro jejich označení. 
Jak již sám název knihy napovídá, Gellner rozlišuje tři základní struktury, jež jsou časově řazeny za sebou, takže jde zároveň o epochy: tu prvou, metaforicky vyjádřenou pluhem, někdy označuje jako epochu „prvotní“; tu druhou, kterou symbolizuje meč, nejčastěji jako agrární či feudální a tu tř̌etí, jíž opatřuje znamením knihy, jako „nový řád“, současnost, kapitalismus, prostě moderní společnost.

Prvá skeptická otázka historikova může znít: co je na tomto trojdělení nového? Lze na to namítnout, že sice členění dějin na tři epochy je banalita, ale rozhodující rozdíly spočívají v tom, čím se jednotlivé epochy charakterizují. Právě o to se ve svém příspěvku hodlám pokusit. Chci zjistit, zda v Gellnerově textu nalezneme nové charakteristiky oněch proměn a systémů, jež při periodizaci bereme v úvahu a které se nám zdají být obecně známé. Zajímá mne pochopitelně především ona druhá a třetí epocha, a to se zvláštním zřetelem $\mathrm{k}$ procesu přechodu mezi nimi - transformace od předmoderní $\mathrm{k}$ moderní společnosti. Naproti tomu přenechám tematiku přechodu od prvotní společnosti ke společnosti „meče“ kvalifikovanějším autorům.

Čím tedy charakterizuje Gellner (zejména ve 4. kapitole své knihy) onu nejstarší dějinnou epochu - agrární společnost, která je podle jeho soudu založena na „agrární revoluci“? Zde naráží naše interpretace na další nejistotu. I když se zdá být logické, že onou agrární revolucí je tř̌eba chápat obrat k obdělávání půdy, který proběhl v neolitu, místy se zdá, že se autorovi tato revoluce prolíná s raně středověkou kolonizací. At již tak, či onak, lidé žijící v době, která po zemědělské revoluci následovala, byli závislí na půdě a jen díky jejímu obdělávání byli schopni přežít. Postupně dokázali nejen vyrobit přebytky, tedy víc, než bezprostředně potřebovali k obživě, ale také je uchovávat v „uskladnitelných zásobách“ [Gellner 1988: 131]. Teprve následně umožnil onen revoluční obrat k zemědělství také nové uspořádání společnosti, tedy přechod ke společnosti „meče“.

Pokrok ve výrobě umožnil, aby vznikla skupina lidí, kteři si násilím nadvýrobek přivlastnili a libovolně jej přerozdělovali, přičemž téměř neexistovala tržní redistribuce [Gellner 1988: 163]. Tito „hrdlořezové“ společnost ovládli a určovali její povahu. Základním rysem jejich vlády se stal kult násilí, jež uplatňovali nejen vůči porobenému obyvatelstvu, ale také vůči sobě navzájem. Násilí bylo v kontextu jejich doby hodnotou, ale zároveň i sebezničující hrozbou, poněvadž otevíralo dveře boji všech proti všem. Proto potřebovala tato společnost nějaké sjednocující náboženství, kult, který „potvrzuje a posiluje“ vědomí, že vládnoucí násilníci mají také něco společného. Zároveň potřebovala ze stejného důvodu také mechanismy nastolující aspoň dočasně rovnováhu sil mezi těmi, kdo jí vládnou. Tento mechanismus rovnováhy dostal obvykle podobu autoritářského režimu [Gellner 1988: 133], tedy - vyjádřeno terminologií historiků - podobu centralizované monarchie, resp. absolutismu.

Gellnerovy charakteristiky vnitřního fungování agrární společnosti přinášejí řadu neotřelých postřehů, které do jisté míry obohacují obraz oné epochy. Mezi nimi si zaslouží zmínku zejména rozlišení moci, kterou vládnoucí násilníci uplatňovali, na primární, kdy vnucovali ostatním svoji vůli fyzickou hrozbou, a sekundární, kdy jedinec či skupina využívá sociálně vnucená pravidla, aby zlomila vůli někoho druhého [Gellner 1988: 132]. Jinou pozoruhodnou charakteristikou je konstrukce souvztažnosti a vzájemného podmínění mezi exkluzivní koncentrací moci a velkou ekonomickou nerovností. Důležitý je také poznatek, že zemědělce v odlehlých chudších a méně přístupných oblastech bylo 
obtížné znevolnit, takže ti si udrželi jistý stupeň nezávislosti. Podobně se plnému porobení ubránila také pastevecká společenství.

Nejednou však jsou Gellnerovy charakteristiky mylné, či přesněji řečeno v rozporu s běžně přijímanými názory historické vědy. Tak např. názor, že násilí v agrární společnosti „nedbá pravidel“ [Gellner 1988: 133], je př́lišným zjednodušením. Je totiž nutno diferencovat podle toho, vůči komu se násilí uplatňovalo. Tam, kde šlo o vztah mezi panovníky navzájem a také mezi př́islušníky vládnoucí tř́idy uvnitř státu, totiž určitá pravidla existovala a byla do značné míry respektována, zatímco násilí bez pravidel bylo aplikováno ve vztahu k poddaným, at již to byli rolníci nebo - jak si správně Gellner všímá - měštané. Ani to však neplatí absolutně, poněvadž postupně se ve stále větší části Evropy začalo také vykořistování rolníků, tj. přivlastňování rolnického nadvýrobku, stejně jako vybírání dávek od měst, řídit jistými pravidly. Stačí poukázat na příklad emfyteuse či na hospodářská a politická privilegia, která si města získávala.

Také Gellnerova teze, že „měštanstvu nechávají vládcové jen odměnu ve výši minima potřebného k jeho reprodukci“, potřebuje upřesnění historikovo. Toto konstatování zhruba platí pro vztah k rolnictvu, nikoli však pro vztah k měštanstvu. Bylo to právě měšłanstvo, jež se dokázalo vymanit z této násilnické libovůle vládců. Významu města jako svébytné síly, jejíž význam přesahoval rámec společnosti meče, si je ostatně autor vědom, poněvadž na jiném místě označuje město velmi př́hodně za „jediný výchozí bod z agrární sociální organizace“ [Gellner 1988: 136]. K jeho názorům na roli města se bude vhodné vrátit v souvislosti s modelem přechodu od agrární k moderní společnosti.

$\mathrm{V}$ těchto korekcích a upřesňováních některých Gellnerových formulací by bylo možné pokračovat, ale nepřispělo by to nijak podstatně k analýze problému periodizace. Mohlo by to naopak být považováno za zbytečně školometskou kritiku. Proto bych rád věnoval pozornost procesu, který považuji za ústřední pro zrod moderní společnosti, tj. k otázce, jak a případně také proč došlo k proměně společnosti „meče“ ve společnost „knihy“, tedy k proměně společnosti tradiční, agrární ve společnost moderní, kapitalistickou. Tento proces přechodu je ostatně tématem, ke kterému jsem se ve svých mladších letech stále znovu vracel. Hovoříme-li o přechodu, transformaci, pak je třeba především si nejprve ujasnit výchozí situaci. Jakou podobu mělo to, co se postupně přežilo, resp. přetvářelo?

Je třeba si proto znovu položit otázku, čím vlastně Gellner určuje onu agrární společenskou strukturu. Shrnu zde jeho výše uvedené charakteristiky pro lepší přehlednost do několika základních bodů: za prvé půda je základním prostředkem, z níž společnost čerpá obživu; za druhé když zemědělec vyprodukuje nadvýrobek a je schopen jej skladovat, umožní to, aby se nadvýrobku postupně zmocnili ti, kdo následně rolníka porobí; za třetí násilí a přinucení ve vztahu vládnoucích a ovládaných je tedy konstitutivním prvkem této společnosti; za čtvrté rozdělování nadvýrobku je především určováno vládci, tedy rozhodnutími, která leží mimo tržní vztahy.

Tento přehled znaků by měl nejednomu příslušníkovi starší generace něco připomínat. Jde o charakteristiky, které totiž ve své podstatě, byt nikoli ve své verbalizaci, odpovídají tradiční marxistické koncepci feudálního systému (či feudální společenskoekonomické formace). Ponechám ted’ stranou učebnicové definice a odkážu na charakteristiku feudalismu, již formuloval mladý Vladimir Iljič Lenin ve své první (a myslím nejlepší) práci o vývoji kapitalismu v Rusku. Kromě označení půdy za základní výrobní 
prostředek mimoekonomického přinucení jako hlavního rysu ekonomiky a převahy naturálních vztahů nad tržními najdeme u Lenina navíc ještě dvě charakteristiky: odkaz na tradiční povahu výroby a stagnaci v povaze výrobních nástrojů je v podstatě kompatibilní s tím, jak epochu charakterizuje Gellner. Naproti tomu je zásadní rozdíl v tom, že Gellner neužívá k označení sociální stratifikace oné společnosti termínů třída a třídní boj. I když jeho charakteristika „bojovníkư“, kteří společnosti vládnou, nemá daleko k tomu, co marxisté označují jako třídu. Naopak u Lenina pochopitelně nenajdeme odkaz na sjednocující a modifikující roli náboženského kultu, faktory, jimž Gellner opodstatněně přikládá zásadní důležitost pro udržení konsistence společenského systému.

Tímto srovnáním nechci naznačovat názorovou blízkost obou autorů, i když určitý jejich společný jmenovatel by bylo možno nalézt. Co však můžeme ze srovnání vyvodit, je metodicky důležitý poznatek, že shoda mezi dvěma názorově i časově tak vzdálenými autory, na kterou zde upozorňuji, vyplývá z toho, že existuje - a existoval již od konce 19. století - značný konsenzus v názoru na základní rysy oné společnosti, jíž jedni říkají agrární, jiní tradiční a ostatní feudální. Odlišnosti najdeme - vedle rozdílné verbalizace - spíše v tom, jaký důraz kladli rozdílní badatelé na jednotlivé charakteristiky a také v tom, do jakého časového kontextu je zařazovali. Jinak řečeno, nejen banální chronologické údaje, ale také jistá zobecnění přijímají jako východisko své analýzy autoři, jejichž ideologická východiska mohou být značně rozdílná. Je možné zpochybnit a odmítat termín „feudalismus“, ale tím není popřena skutečnost, že je užitečné rozlišovat jistá stádia, epochy ve vývoji společnosti, přičemž se na určení základních znaků těchto stádií většina badatelů shoduje, jakkoli je rozdílně nazývá a interpretuje. Ostatně i náš autor termínu feudalismus užívá a dokonce jej označuje za „matečnou půdu kapitalismu“ [Gellner 1988: 143].

Významným Gellnerovým př́nosem není podle mého názoru charakteristika agrární či feudální společnosti - ta obsahuje, jak jsem právě uvedl, věci obecně známé či konsenzuálně přijatelné. Inovativní a inspirující jsou spíše jeho sofistikované úvahy o tom, jak se agrární společnost proměňovala - čili jaké byly „podmínky úniku“, jak nazývá jednu z podkapitol.

Slabinou ortodoxně-marxistické koncepce byla neschopnost či neochota hledat kauzální souvislosti přechodu od formace feudální ke kapitalistické a jejich specifika v podmínkách rozdílných zemí. K tomu patřilo také zploštění výkladu kauzálních souvislostí odkazem na „historickou nutnost“. O překonání tohoto nedostatku usilovala vlastně až diskuze anglických marxistů a nemarxistů po 2. světové válce, která se táhla až do konce 60. let. ${ }^{2}$ Tuto diskuzi Gellner ve svém výkladu o „úniku“ z agrární společnosti vůbec nereflektuje, at již proto, že ji nezná nebo dokonce proto, že ji záměrně ignoruje. At tak, či onak, z hlediska tradičních pravidel historické vědy je takové opomenutí závažným nedostatkem. Nevím, zda v antropologii je běžné nebrat v úvahu starší názory, které se autorovi nelíbí. Nicméně v metodice historické vědy patří již od 19. století k základním proseminárním poučkám, že autor nejen musí vědět, co se o problému, jímž se zabývá, napsalo v minulosti, ve starší odborné literatuře, ale má také k jejím názorům zaujmout stanovisko, resp. sdělit, v čem je jeho postup či řešení od starší literatury odlišné.

2 Soubor nejdůležitěǰších statí vydal Roger Hilton, Transition from Feudalism to Capitalism. London: Verso, 1976. 
Takové zamyšlení bohužel u Gellnera nenajdeme - a je to škoda již proto, že např́klad tzv. Brenner debate ${ }^{3}$ se pokoušela najít odpověd’ na protimluv, kterého si je vědom [Gellner 1988: 137], když uvádí, že pro radikální průlom a únik „Zz agrární slepé uličky“ hrála důležitou roli existence výrobců, kteří se dokázali vyhnout či dokonce ubránit útlaku a znevolnění (tedy lidí svobodných) - ale na druhé straně existence takových lidí byla „V rozporu s logikou agrární společnosti“.

Základní faktor změny vidí Gellner především v působení měst, pokud se stala administrativními a výrobními i obchodními středisky a proměnila se v základnu pro „autonomní činnost“ nezávislých obchodníků. Městské obchodní pospolitosti, pokud si vytvoří vládu „rovnováhy moci“, byly schopny stát se „zprostředkovatelem průlomu z agrárního světa“.

Ale jak se mohla města stát takovým zprostředkovatelem, když byla podřízena systému, kde „přebytek nahromaděný výrobci“ si jednak přisvojovali bojovníci, jednak byl vynakládán na „rozmnožení rituální výbavy společnosti“? Z toho vyplývá, že „nadbytek se nikdy nepoužíval ke zvýšení výrobního vybavení společnosti“. Tento začarovaný kruh prolamuje v Gellnerově modelu teprve reformace, přesně řečeno kalvinismus. V tom zaujímá postoj blízký a vědomě se vztahující ke konstrukci Maxe Webera o zrodu kapitalismu z „ducha kalvinismu“, která byla opakovaně diskutována a historiky již $\mathrm{v}$ jeho době většinou odmítána. ${ }^{4}$ Za přesvědčivý a přijatelný v této konstrukci považuji, ve shodě s dalšími autory té doby, názor, že kapitalistický typ podnikání - tedy investici nadbytku do výroby - máme doložen v jistých oblastech již před reformací a že kalvinismus byl s takovýmto podnikáním kompatibilní. ${ }^{5}$

Klíčový problém tkví zde $\mathrm{v}$ otázce, zda bychom neměli rozlišit tři fenomény. Za prvé prostou podnikavost za účelem dosažení jistých výhod a případně i finančního zisku, která je něčím jako antropologickou konstantou. Za druhé společenské podmínky pro uplatnění takové podnikavosti a konečně za třetí ideologické zdůvodnění, respektive mravní apologii takového podnikání, které mohlo, ale nemuselo dostat podobu onoho kalvinistického „ducha kapitalismu“, jak jej konstruuje Max Weber. Snad bychom mohli označit tržní vztahy či spíše na trh orientovanou ekonomiku (byt̉ jen částečně) za obecný předpoklad, za jakousi „prrírodní realitu“, a kalvinismus pak za jakousi „kultivaci“ této syrové sociálně-ekonomické reality.

Weberova teze o městské autonomii jako dynamizujícím, resp. rozkládajícím prvku agrární společnosti je zajisté kompatibilní nejen se základní tezí neortodoxního marxismu, ale stejně tak i s Gellnerovým výše zmíněným názorem, že město zprostředkovalo „průlom z agrárního světa“. K tomu Gellner připojuje konstatování, že nejednou sami „bojovníci“ pomáhali při ochraně růstu obchodních center, když se vládce spojoval s měštany ve svém konfliktu s odstředivými tendencemi baronů. Také zde jde o poznatek, který historická věda v obecné poloze přijímá jako jeden z několika, ale nikoli za jediný možný kauzální vztah.

3 Př́́spěvky do diskuze, která proběhla na stránkách časopisu Past and Present, vydali T. H. Ashton a C. H. E. Philpin (eds.), The Brenner Debate. Agrarian Class Structure and Economic Development in Pre-Industrial Europe. Cambridge: Cambridge University Press, 1985.

4 Diskuzní příspěvky shrnul Johannes Winckelmann (Hrsg.) ve 2. svazku edice Max Weber. Die protestantische Ethik. Eine Aufsatzsammlung. München - Hamburg: Siebenstern-Taschenbuch-Verlag, 1968. Tawney, R. H.: Religion and the Rise of Capitalism. London: John Murray, 1925. 
Opodstatněně Gellner upozorňuje, že úspěšná vzpoura ovládaných, kteří dokáží svrhnout stávající vládce a „vystřídat kádry“, ještě nemůže být automaticky považována za systémovou změnu ani za změnu éthosu, poněvadž noví vládcové budou i nadále především uplatňovat svoji moc silou. Nebudou totiž mít ve „standardním stavu“ agrární společnosti motivaci k tomu, aby jednali jinak. Pro vysvětlení systémové změny je proto třeba hledat výklad.

Ústřední místo v Gellnerově výkladu příčin přechodu k moderní společnosti má soubor mechanismů, které ve své kombinaci umožňovaly „erozi donucovacího řádu“ a následně „únik“ z agrární feudální společnosti, tj. přechod ke společnosti moderní. V tomto směru působila vedle městského prostředí ještě řada dalších závažných okolností a souvislostí, které jsou rozčleněny do patnácti bodů v kapitole „Podmínky úniku“.

Dovoluji si je nejprve seřadit a pojmenovat - a pak teprve interpretovat. Soustředím se zejména na ty $\mathrm{z}$ oněch patnácti bodů, které aspoň částečně reflektuje také historiografie a kde tedy Gellnerův výklad jaksi souzní s převládajícími názory historické vědy. Je přitom otázkou, zda můžeme najít souvztažnost alespoň mezi některými z charakteristik, které Gellner jen řadí jaksi vedle sebe, aniž se ve většině případů pokouší o to, vytvořit z nich jakýsi systém, resp. strukturu. I když nemyslím, že z oněch patnácti glos je možné ucelený systém konstruovat, je zřejmé, že některé $z$ nich je možno uvést do jisté souvztažnosti.

Průlom $\mathrm{k}$ nové ekonomice byl nemyslitelný $\mathrm{v}$ podmínkách malých přebytků výroby. Předpoklad změny byl dán teprve tehdy, když se produkce zvýšila, což bylo nemožné bez inovací v podobě vzepětí „technické síly“, která byla součástí či produktem zájmu o technické inovace. Rozhodujícím prostorem těchto inovací bylo městské prostředí.

Inovace $\mathrm{v}$ technologii však byly možné teprve za jistých společenských, resp. politických podmínek, nebở extrémní kořistnická politika státu či vrchnosti předem vylučovala zájem potenciálních podnikatelů na aplikaci nových technologií. Platí proto opačný vztah: příznivou podmínkou pro zavádění inovací byla situace, kdy politické centrum dovolovalo, aby se podstatný díl výrobků uplatňoval na trhu s co nejmenším podílem státní či jiné silou uplatňované reglementace.

Rozvoj výroby v autorově pojetí není myslitelný bez volného „nediferencovaného“ trhu, který překonává představu o „spravedlivé ceně“ a zavádí hodnotu jako „funkci uspokojení“. Pro tento trh je ovšem nutnou podmínkou „politický a kulturní rámec“. Povahu tohoto rámce ovšem Gellner nijak neprecizuje. Zajisté sem patří uvolnění podmínek pro podnikání, ale také nově definovaný systém hodnot, $v$ němž právě podnikavost se dostává na přední místo. Zásadní význam pro systémovou změnu měla reformace, která narušila kult potvrzující a posilující „stabilní společenský řád“ a k tomu ještě otevřela dveře novému hodnocení podnikání s cílem co nejvyššího zisku - tedy oné výše zmíněné protestantské etice. Přitom však proměnu „kulturního rámce“ nezužuje Gellner na reformaci, ale upozorňuje na to, že si společnost na jistém stupni vývoje vyvinula specifickou, osvícenstvím formovanou vizi pokroku.

Velmi důležitá byla již uvnitř samotné feudální společnosti rostoucí autorita římského právního dědictví, především oné jeho složky, která chránila soukromé vlastnictví a nedovolovala libovolné konfiskace velkých majetků, které si př́ípadně nahromadili podnikaví poddaní. 
Dále pak Gellner poukazuje na nejméně tři sociální okolnosti, podmínky, které vytvářely možnost, nikoli však nutnost obratu k podnikání. Byla to především „prodyšná aristokracie“, která umožňovala, aby se šlechta zařadila do podnikání. Druhou podmínkou byla existence osobně svobodných rolníků, kteří neživoří, ale dosahují určitého standardu životní úrovně, a konečně třetí podmínkou byla pak taková progresivní změna poměrů ve výrobní sféře, díky níž se výrobci potravin mohli stát menšinou obyvatelstva a umožnili tak růst výrobních sil v řemeslné sféře.

Právě posledně uvedené charakteristiky nabízejí návod ke konkretizaci prostorového určení, k lokalizaci, která je sice vágní, ale kterou jinak u Gellnera postrádáme. Povětšině se totiž Gellner vyjadřoval velmi abstraktně, takže se zdálo, že hovoří obecně o vývoji společnosti, ale na tomto místě naznačuje, že má na mysli pouze jednu nepř́liš rozsáhlou část Evropy. Specifikaci této části Evropy si můžeme vymezit a pojmenovat ji také podle náznaku o prostupné šlechtě, o rozvoji nezemědělské výroby či o puritanismu. Teprve v posledním ze svých patnácti bodů je nakonec Gellner konkrétní, když nakonec v posledním bodu kapitoly o přechodu ke kapitalismu hovoří o „ostrovní společnosti, které moře sloužilo jako vodní př́kop a která se těšila z občanských svobod poskytovaných ne jednotlivým městům, nýbrž národnímu parlamentu“ [Gellner 1988: 154]. Autor nám zde implicitně naznačuje i explicitně sděluje, že se nacházíme v Anglii. To samozřejmě není určení překvapující ani nové: stačí připomenout si modelový vztah „core“ a „periphery“ Immanuela Wallersteina, ale vlastně již model mnohem starší, jaký najdeme ve 24. kapitole 1. dílu Marxova Kapitálu.

Náhlé zúžení abstraktního výkladu na jedinou zemi nás ovšem staví před dalšî zásadní metodologický problém. Implikuje totiž předpoklad, že agrární společnost se zhroutila pouze na jediném místě v Evropě a vlastně i ve světě. Implikuje také hypotézu, že se nový moderní věk, kapitalismus, zrodil jen v Anglii, a pak se odtud jakýmsi politicko-ekonomickým transferem šíril do Evropy i světa. Taková představa ovšem je diskutabilní a zdá se, že neobstojí v konfrontaci s poznatky hospodářských a sociálních dějin.

Ostatně by nebylo seriózní, kdybychom Gellnerovi podsouvali, že takový názor zastává jednoznačně. Nebot̉ již v samotném závěru této kapitoly svůj výklad na jedné straně relativizuje (když říká „třeba nemám pravdu, nevíme dost přesně, proč se to stalo“) a na druhé straně jej formuluje tak obecně, že je možné jeho výklad chápat jako charakteristiku jakési opakující se pravidelnosti, tedy modelu, podle kterého se, pokud nastaly obdobné podmínky, mohl kapitalismus zrodit také na jiném místě.

V tomto modelu se říká, že průlom do agrární společnosti a obrat k jejímu překonání byl možný tam, kde existovala zákona dbalá vláda; kde existovala podnikatelská třída, která měla jisté politické svobody, ale nedychtila po dominanci. Existovala také tam, kde rostla možnost výskytu aplikovaných technických inovací.

To vše je řečeno nejen s vědomou lokální neurčitostí, ale také jakoby mimo dosah časového určení. Je to tak neurčité, že bychom mohli Gellnera domýšlet a předpokládat, že onen průlom do agrární společnosti se mohl zrodit asynchronně a s rozdílnou dynamikou na různých místech Evropy a že převaha Wallersteinova „core“ se prosadila až poté, co patřičně zesílily obchodní vztahy v procesu utváření evropského a světového trhu.

K těmto předpokladům, které jsou veskrze v souladu s historickým poznáním, by ovšem historik na základě banálních empirických poznatků doplnil ještě další důležitý předpoklad, který u Gellnera chybí. Výklad vzniku toho nového totiž nezahrnuje otázku, 
zda ve staré společnosti najdeme také síly, které směřovaly kupředu, a nezabývá se ani tím, které okolnosti působily jako faktory rozkladu staré agrární společnosti. Jinak řečeno, zdá se mi, že Gellnera nijak zvlášt nezajímají krizové jevy, dysfunkce, jež vyplývaly z rozporných vývojových tendencí samotné agrární společnosti.

Nevím, zda to je jen opomenutí, záměr nebo neochota připustit, že uvnitř agrární společnosti se rodily rozpory, resp. dysfunkce, které tato společnost nebyla schopna zvládnout - např́klad rozpor mezi nárůstem výroby zboží na jedné straně a peněžních vztahů a na straně druhé rozpor, který byl vyprovokován „libovolným rozdělováním“ - tj. parazitickým a neproduktivním využíváním těchto množících se zdrojů. Pokud by takový rozpor připustil, musel by počítat s teoretickou možností, že vnitřní otřesy a krize agrární společnosti mohly vznikat nezávisle na sobě v různých zemích Evropy. Znamenalo by to pak, že také „průlom“ k nové, moderní společnosti se začal prosazovat nikoli výlučně na jednom, ale na několika místech nezávisle na sobě. Nástup průlomové situace ovšem nemusel všude vyústit v utváření nové kapitalistické struktury, jak to proběhlo v Anglii.

Vedle relativně „čistého“ kapitalismu anglického známe přece v mnoha evropských zemích př́pady toho, že starý systém - obvykle absolutismus - v sobě najde schopnost integrovat nové prvky podnikání a využívat jich pro své další fungování, ted' však již nikoli v rámci zcela libovolného, nýbrž stále více ekonomicky regulovaného přerozdělování. Samozřejmě, i v těchto zemích byl tento proces doprovázen otřesy, ale zároveň se perspektiva či vize nového systému transformovala do nových ekonomických projektů, jako byl merkantilismus, fyziokratismus a především pak tzv. klasická politická ekonomie Adama Smithe.

Zde stojíme zároveň před jednou ze zásadních metodologických otázek, které musí znepokojovat nejen historika. Jestliže totiž budeme Gellnerův výklad interpretovat tak, že - řečeno s brutální jednoduchostí - Anglie byla kolébkou kapitalismu, jenž se pak odtud šíril dál. Jestliže by tedy Anglie byla jediným ohniskem přechodu ke třetí etapě vývoje lidstva, pak se tato etapa, tato moderní společnost rodila vskutku jakoby nahodilou shodou příznivých okolností. V této interpretaci Gellner nechce připustit, že by existovala nějaká pravidelnost dějin, třeba $v$ tom, že na obdobné proměny ekonomiky a politiky reagují lidé na různých místech obdobně. Proto je logické, že musí zastávat teorii jediného ohniska změny od agrární ke kapitalistické společnosti. V tomto kontextu asi musíme brát vážně jeho výroky typu „zázračná politická a ideologická rovnováha moci“.

Takovýto postoj má svoji legitimitu, ale zároveň se ve zpo̊sobu, jak jej Gellner aplikuje, skrývá závažná metodologická slabina. Pokud totiž jeho koncept přijmeme, pokud se tedy z anglického „prvního hospodářského zázraku“ šíril kapitalistický moderní věk po Evropě a světě, potom by ovšem čtenář měl právo od autora očekávat, že si položí otázku, jakými cestami a podle jakých mechanismů transferu se nový typ společnosti z anglického ohniska šíril do „periferie“. Zde se opakovaně nabízí paralela s Wallersteinem a Marxem. Wallersteinova polarita mezi „core“ a „periphery“ tak trochu souzní s Gellnerovou představou jednoho ohniska, ale její autor věnuje obrovské úsilí tomu, aby vysvětlil právě onen transfer. Naproti tomu Marx jakoby předpokládal zákonitý vývoj ke kapitalismu na různých místech, což mu umožňuje ignorovat otázku transferu. At tak, či onak, máme zde co činit s fenoménem nerovnoměrnosti vývoje, který koneckonců tematizuje také Gellner, ovšem teprve v závěru a jaksi na okraji své knihy. 
Ani zde není autorův postoj jednoznačný a v jeho textu lze najít řadu dokladů o tom, že si byl vědom nerovnoměrné povahy proměn společnosti a považoval tuto nerovnoměrnost za badatelský problém. Právě tak se nejednou setkáme s tím, že předpokládá opakovatelnost určitých procesů, které probíhaly navzájem nezávisle. Tak je tomu např́íklad tam, kde uvažuje o konstrukci obecného mechanismu trhu [Gellner 1988: 165 a nn.], nebo tam, kde hovoří o dělbě práce jako o zdroji dalších jakoby přírodních, tj. na lidské vůli nezávislých změn nebo o „mechanismech“ a nestálosti či stálosti stavebních kamenů dějin společnosti [Gellner 1988: 182].

Zajisté, problémy, jimiž se zde zabývám, netvoří jádro Gellnerovy knihy a nelze vyloučit, že je ani autor nepovažoval za kardinální. V tomto příspěvku mi však nešlo o to, vyložit jeho dílo jako celek ani recenzovat jeho knihu. Mým cílem bylo na jedné straně ověrit si, do jaké míry se může historik poučit u antropologa, na druhé straně kriticky prověřit, do jaké míry antropologické konstrukce obstojí tváří v tvář poznatkům historické vědy. Soustředil jsem se přitom na tematiku, která je mi badatelsky nejbližší, na problém přechodu od předmoderní k moderní společnosti.

Při vší specifice jednotlivých společenskovědních oborů a jejich metod je důležité, že jedno je spojuje, a to je předmět studia - lidská společnost a její vývoj. Každý obor by se tedy měl snažit především aspoň částečně pochopit, jaké byly rozdíly př́ístupu, rozdíly v metodách různých společenskovědních oborů. Takového cíle lze nejsnáze dosáhnout tehdy, sledujeme-li, jak př́buzné obory postupují při analýze téhož relevantního problé$\mathrm{mu}, \mathrm{v}$ tomto př́padě tedy problému periodizace a zejména přechodu od předmoderní k moderní společnosti. Snažil jsem se při tom na jedné straně ověřit, jaké možnosti má historik, chce-li se poučit z poznatků a postupů př́buzného společenskovědního oboru a získat tak inspiraci pro historickou práci. Na druhé straně ovšem je nutno vzít v úvahu, že naopak antropolog, sociolog, politolog má možnost využít empirických poznatků historické vědy k upřesnění a ověření svých konstrukcí a modelů.

Dospívám tak k banálnímu závěrečnému konstatování, že jednotlivé obory se mohou svými specifickými př́stupy vzájemně obohacovat a inspirovat, ale že přitom každý obor zároveň má brát v úvahu meze svých možností.

Miroslav Hroch působil do roku 2000 jako profesor obecných a komparativních dèjin filozofické fakulty UK, nyní prednáší historii na fakultě humanitních studií UK. Zabýval se problematikou formování moderních národi̊ v Evropě, nerovnomèrností evropských dějin a problematikou přechodu ke kapitalistické společnosti. Nejnověji publikoval práce Comparative Studies in Modern European History (2007) a Národy nejsou dílem náhody (2010). 